\title{
Formulation of Cost Effective Diets with Different Energy Levels and their Effects on Broiler Chicken
}

\author{
Irfan Jan ${ }^{1}$, Abdul Kabir ${ }^{2}$, Laiba Uroog ${ }^{3}$, Shumaila Manzoor ${ }^{4}$, Muhammad Said ${ }^{1}$, Nasir \\ RAJPUT $^{1}$
}

${ }^{1}$ Department of Poultry Husbandry, Faculty of Animal Husbandry and Veterinary Sciences, Sindh Agriculture University Tandojam, Pakistan; ${ }^{2}$ Department of Veterinary Microbiology Faculty of Animal Husbandry and VeterinarySciences Sindh Agriculture University, Tandojam Pakistan; ${ }^{3}$ Animal Microbiology and Immunology laboratory, Department of Animal Sciences, Faculty of Biological Sciences, Quaid-i-Azam University, Islamabad, Pakistan; ${ }^{4}$ National Veterinary Laboratory, Park road, Islamabad, Pakistan.

\begin{abstract}
The purpose of this study was to decrease the cost of feed without adversely affecting broilers performance. An experiment was conducted to study the effect of functional oils (soybean oil and castor oil) in diets with different metabolizable energy (ME) levels i.e. 2850, 2750 and $2650 \mathrm{kcal} \mathrm{ME} / \mathrm{kg}$ on the overall performance of broiler chickens from 1 to 42 days. Two hundred and forty, day-old Cobb broiler chicks were randomly divided into four groups with three replicates per group. The results showed that mixing functional oils in feed improved live weight and feed conversion ratio (FCR) of the birds compared with diets with the same ME level. Moreover, functional oils when mixed in weak diets with ME $(2750 \mathrm{kcal})$ showed similar results as control group where ME $(2850 \mathrm{kcal})$ without functional oils. There was a significant difference $(\mathrm{P}>0.05)$ in live body weight, feed intake, FCR, size of intestine while non-significant difference $(\mathrm{P}<0.05)$ in water intake among the groups. Hence it was concluded that addition of functional oils in low energy diets could decrease the cost of feed without any negative effects on production and economics of broiler chickens as compared to high energy diet.
\end{abstract}

Keywords | Broiler, Functional oil, Metabolizable energy.

\author{
Editor | Muhammad Abubakar, National Veterinary Laboratories, Islamabad, Pakistan. \\ Received | October 08, 2018; Accepted | November 18, 2018; Published | December 25, 2018 \\ *Correspondence | Shumaila Manzoor, National Veterinary Laboratory, Park road, Islamabad, Pakistan; Email: shamaleo@hotmail.com \\ Citation | Jan I, Kabir A, Uroog L, Manzoor S, Said M, Rajput N (2018). Formulation of cost effective diets with different energy levels and their effects on \\ broiler chicken. Res. J. Vet. Pract. 6(4): 27-34. \\ DOI | http://dx.doi.org/10.17582/journal.rjvp/2018/6.4.27.34 \\ ISSN (Online) | 2308-2798
}

Copyright $(2018$ Jan et al. This is an open access article distributed under the Creative Commons Attribution License, which permits unrestricted use, distribution, and reproduction in any medium, provided the original work is properly cited.

\section{INTRODUCTION}

$\mathrm{N}$ utritional management is one of the most important aspects for poultry industry. Improvement of poultry production depends on the healthy nutrition that includes feeding of balanced diet which must fulfill basic requirements. Economics of poultry industry mainly depends on the cost efficient feed, for this purpose least cost formulation systems are developed, using such systems availability of good quality feed in adequate quantity at a price that farmers/producers can afford is ensured (Babatunde, 2005). There are many factors that effects on feed con- sumption of poultry birds amongst those hot climatic conditions is of prime importance. Under such condition poultry birds remains under heat stress due to exposure of external temperature and in addition internal heat production. Heat stress causes drop in feed intake thus results in low weight gain that is reason for great economic loss to poultry. To combat with such circumstances, adjustments need to be made in feed formulation by using more dietary fat as energy source instead of carbohydrates (Navidshad, 2009). Fat is usually included in diet formulation to meet the high energy requirements of broiler chickens, as the energy value of fat is at least twice as high as those of car- 
bohydrates and protein. Furthermore, fats slows down the rate of food passage through the digestive tract allowing more time for better digestion and absorption of nutrients. Supply of energy represents the major cost in feed formulations. Due to recent increases in the price of cereals there are increasing interests in exploring ways to improve the energy value of fats. Therefore there is need for greater understanding of the digestions and absorption of fats in poultry. Some plant oils such as castor oil, soybean oil, sunflower oil, canola oil, olive oil etc have been labelled "functional oils" because they have biological activities beyond their energy value. Due to rich energy source and high nutritive value many researchers (Bess et al., 2012; Pesti et al., 2002; Salma et al., 2007) used functional oils as an alternate energy source to carbohydrates in poultry feed. These fats exert many beneficial effects on poultry birds like increase in live body weight and improvement of feed conversion ratio. Besides these effects, feed containing vegetable oils reduces the dustiness of feed, make it more palatable, lower heat production and increase digestibility of broiler chickens (Firman et al., 2008).

Castor oil is unique among functional oils because it is the only commercial source ricinoleic acid. Castor oil has shown anti-microbial and anti-inflammatory activities. It is laxative if used orally but when combined with soybean oil at low dose and mixed in feed it become biologically active thus making it safe for use (Aliyu et al., 2012). Soybean oil contains high percentage of poly unsaturated fatty acids i.e. linolenic and linoleic acids which are well absorbed and utilized as a source of energy. It is good source of omega 3 fatty acids. The high vitamin E present in soybean oil acts as a powerful anti-oxidant which boost the immunity and helps to eliminate the free radicals that cause certain diseases.

\section{MATERIALS AND METHODS}

Two hundred and forty (240) day old Cobb chicks were purchased from local hatchery in Karachi and brought to Poultry experimental station at Faculty of Animal Husbandry and Veterinary Sciences Sindh Agriculture University Tandojam. Before arrival of chicks poultry shed was properly cleaned and fumigated by mixing $40 \mathrm{ml}$ of formalin with $20 \mathrm{~g}$ of potassium permanganate for volume of 100 cubic feet. After sanitization whole shed was coated with limestone and allowed to dry for 24 hours. Birds were reared on deep litter housing system, and each bird was provided $1 \mathrm{sq}$ ft floor space. Litter material (rice husk) was purchased from a local rice mill at Hyderabad and subjected to sunlight heating for 12 hours to completely dry before placing in shed and then spread at floor area up to 2-4 inch depth. Care was taken to maintain optimum temperature and humidity throughout experimental period. To avoid production of toxic gases in shed and wetting of litter material regular turning of litter i.e. 2-3 times was practiced. Availability of required light during the day and night as well as ventilation was ensured through regular monitoring throughout study period. Brooding of chicks was performed under artificial electric brooders with 100 watt electric bulbs.

One brooder and thermometer was provided to each replicate. During first week, brooding temperature was maintained at $90-95^{\circ} \mathrm{F}$ in $1^{\text {st }}$ week and $5^{\circ} \mathrm{F}$ was reduced on each subsequent week till it reached $70^{\circ} \mathrm{F}$, as house temperature. Chicks were vaccinated against Newcastle and Infectious Bronchitis disease on $3^{\text {rd }}$ day via eye drop, Infectious Bursal disease on 10th day in drinking water, Hydro pericardium syndrome on 17 th day in drinking water, Newcastle disease on $22^{\text {nd }}$ day and Infectious Bursal disease on $28^{\text {th }}$ day in drinking water respectively.

A mixture of two functional oils in a fixed ratio of $50 \mathrm{ml}$ castor oil and $450 \mathrm{ml}$ soybean oil was prepared and mixed in each of $100 \mathrm{~kg}$ experimental diet having different metabolizable energy levels by using spray pump to examine the effect of functional oils on the overall performance of broilers fed different energy level diets. The following experimental design was used:

Group A: Industry standard feed having $2850 \mathrm{kcal} \mathrm{ME} / \mathrm{kg}$ without functional oils

Group B: Feed having $2900 \mathrm{kcal} \mathrm{ME} / \mathrm{kg}$ with the addition of functional oils $5 \mathrm{ml} / \mathrm{kg}$.

Group C: Feed having $2750 \mathrm{kcal} \mathrm{ME} / \mathrm{kg}$ with the addition of functional oils $5 \mathrm{ml} / \mathrm{kg}$.

Group D: Feed having $2650 \mathrm{kcal} \mathrm{ME} / \mathrm{kg}$ with the addition of functional oils $5 \mathrm{ml} / \mathrm{kg}$.

\section{Parameters of Study}

Feed intake: Fresh feed was provided twice daily and feed refusal was recorded from feeders of each group. Following formula was used for determination of feed intake per day per chick.

Feed intake $(\mathrm{g})=\underline{\text { Total feed offered }- \text { Total feed refused }}$ Total no of broiler

Water intake: Fresh and clean water was given adlibitum. Water intake was calculated by following formula:

Water intake $(\mathrm{ml})=$

Total water offered - Total water refused

Total no of broiler

Live body weight: Eight birds from each group were randomly selected and weighed weekly by using electric weighing balance. 
Feed Conversion Ratio (FCR): FCR was calculated on the basis of total feed consumed by a broiler bird for gaining one $\mathrm{kg}$ weight. Thus, following formula was used.

\section{$\mathrm{FCR}=\quad$ Feed intake $\times 100$}

Live body weight

Dressing percentage: After the end of experimental period of 42 days, 05 birds from each group were weighted and slaughtered. After dressing, the carcass weight was noted and its dressing $\%$ was recorded by the following formula.

\section{Dressing $(\%)=\quad$ Carcass weight $(\mathrm{kg}) \times 100$ Live body weight $(\mathrm{kg})$}

Size of Intestine: At the end of experiment three birds from each group were slaughtered. Their intestines were removed and washed with cold distilled water. After cleaning the intestines, the length $(\mathrm{cm})$ was measured by using inch tape and compared to study the effect of functional oils on the intestine.

Weight of edible and non-edible organs: Five birds were slaughtered from each group, after slaughtering relative weight of liver, heart; gizzard, spleen and proventriculus were recorded.

\section{DigestibiLity}

Fecal Samples Collection: One bird per replicate was shifted to a separate pen during the age of $36 \mathrm{~d}$. After the adaption period of three days; feces were collected at morning and evening for three days (39 to $41 \mathrm{~d}$ for finisher period) and for further analysis stored at about $-20^{\circ} \mathrm{C}$. Consumption of feed was also noted during this phase.

Chemical Analysis of Samples: Fecal samples were dried in hot air oven at $65^{\circ} \mathrm{C}$ for $24 \mathrm{hrs}$. For proximate chemical analysis the grinder was used in order to obtain reasonable and uniform particle size of feed and feces. For Dry Matter determination, 0.9 to $1 \mathrm{~g}$ sample was filled in a preweighed empty crucible, kept in oven at $105^{\circ} \mathrm{C}$ for $3 \mathrm{~h}$ and weighed afterwards. With methanol fat was extracted by soxhlet method. Performance of the ether extract was calculated with the subsequent formula:

$$
\mathrm{EE}(\%)=\frac{\text { Weight of ash }}{\text { Sample of Weight }} \times 100
$$

Bomb calorimeter was used to measure the gross energy and Kjelldhal method was performed to determine the crude protein contents. Sample was digested with concentrated $\mathrm{H} 2 \mathrm{~S} 04$ in the presence of catalyst mixture containing $\mathrm{K} 2 \mathrm{SO} 4$ and $\mathrm{HgSO} 4$. The Digested feed sample was diluted to definite volume with water. A known aliquot of the diluted feed sample was mixed with $40 \% \mathrm{NaOH}$ solution to an excess alkaline reaction and mixture was distilled with steam in micro-kjelldhal apparatus. The ammonia so liberated was collected in $10 \mathrm{ml} \mathrm{N} / 20 \mathrm{HCL}$ having a few drops of methyl red as an indicator. The excess of the acid was measured by titrating against standard N/20 $\mathrm{NaOH}$ solution. The amount of N/20 NH liberated was determined by difference. Apparent nutrients retention was calculated and expressed as a percentage (Rajput et al., 2012).

Mortality Percentage: Mortality was recorded on daily basis birds were examined and finally, mortality \% was noted by the following formula:

\section{Mortality $(\%)=\quad$ Total No. of birds died $\times 100$ Total reared birds}

Economics: Economics of broilers were calculated by using following formula:

Net returns $=$ income - expenditure

\section{Data Analysis}

The data was collected from all the groups and analyzed statistically by using JPM Software of SAS, USA.

\section{RESULTS}

Figure 1 shows the feed and water consumption of broilers. Feed intake was significantly increased $(P<0.05)$ in groups receiving functional oils even in low energy level diets. Water intake was increased $(\mathrm{P}>0.05)$ in all experimental treatments receiving functional oils.

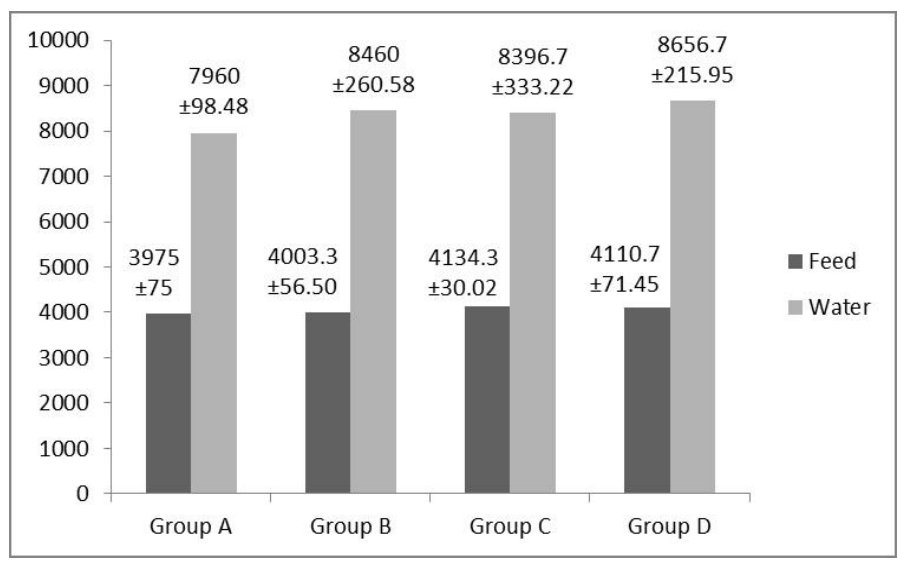

Figure 1: Effect of functional oils on feed and water intake of broilers fed different energy level diets

\section{DISCUSSION}

Functional Oils are commonly used as energy source in poultry ration. Benefits of using functional oils are low dustiness of feed, increased absorption and digestion of 
lipoproteins and have higher amount of necessary fatty acids. Keeping in view, this experiment was performed to sort out the effect of functional oils (castor oil + soybean oil) on the overall performance of broiler fed different energy level diet. The results of all parameters are discussed below.

Feed intake was higher in Group D as compared to control. The higher feed intake might be due to the addition of functional oil mixture i.e. soybean oil and castor oil in diet because soybean oil contain polyunsaturated fatty acid "omega 3" which have a clean taste and pleasant flavour. Soybean oil contains vitamin $\mathrm{E}$ which is a fat-soluble vitamin and essential for the proper nutrition of chickens. Castor oil improves the digestion when mixed with feed in minute quantity. Decreasing the energy value of feed and supplementation with functional oil mixture increased feed intake. Current study was supported by the observations of (Bess et al., 2012) that feed consumed by the broilers in functional oils group was significantly higher than control. Likewise (Scaife et al., 1994) fed broilers with rations containing different sources of lipids (beef tallow, soybean oil, canola oil, and marine fish oil) and observed that feed intake was significantly higher when soybean oil was used. Moreover the use of higher poly unsaturated fatty acids levels which is found mostly in vegetable oils in broilers diet causes higher feed intake and feed gain ratio as described by (Zollitsch et al., 1997) but the results were not always same as cited by (Ajuyah et al., 1993). Controversial findings were reported by (Firman et al., 2010) that use of fat sources in broiler's diet decrease feed consumption and enhances feed efficiency.

Incorporation of functional oils developed the broiler thrust and consumed more water as compared to control (Vieira et al., 2003). Highest water intake was observed in Group D where metabolizable energy level of diet was least i.e. $2650 \mathrm{k}$.cal (Table 1). The reason for increased water intake in Group D was higher concentrations of wheat bran (12.49\%) used to decrease the energy density of diet and as a result variation in water to feed ratio was noted. Current study is supported by the observations of (Huang et al., 2011) who reported that dietary fibre and form of feed affects water to feed ratio. Variation in feed to water ratio was observed in broilers of group $B$. The reason for increased water intake in this group was high metabolizable energy diet which increases broilers thrust and hence increased water intake was noted. Such observations agree with (Serrano et al., 2013) who observed that increasing dietary energy level of feed in broilers caused an increase in water intake which is beneficial during hot season.

Maximum live body weights were noted in Group B as compared to control (Figure 2). Average live weight increased in birds fed diet containing soybean oil (Hossain and Das, 2014).The reason for the increased live body weight was high digestibility and metabolizable energy of soybean oil (Anjum et al., 2004) Castor oil provides about 8 calories of energy per gram. Soybean oil provides about 9 calories of energy per gram. Per $100 \mathrm{~g}$, soybean oil has $16 \mathrm{~g}$ of saturated fat, $23 \mathrm{~g}$ of monounsaturated fat, and 58 $\mathrm{g}$ of polyunsaturated fat. The live body weight in Group D resulted in slightly lighter birds as compared to control but the difference was non-significant $(p<0.05)$. Hence it was proved that these functional oils i.e. soybean oil and castor oil in low dose not only increased live body weight of broilers but also allowed to decrease the ME level of feed up to $100 \mathrm{k} . c a l$ and $200 \mathrm{k}$.cal without negatively affecting the live body weight of broilers. Current study is supported by the findings of (Bess et al., 2012) who reported that metabolizable energy of feed could be decreased to hundred kilo calories per $\mathrm{kg}$ of feed by mixing functional oils in feed without negatively affecting the overall performance of birds.

The best FCR of 1.71 was recorded in Group B as compared to the birds in control group where the FCR of 1.82 was observed. The reason for best FCR may be related to the vitamin $\mathrm{E}$ present in soybean oil. Vitamin $\mathrm{E}$ had significant effect on feed intake and weight gain in chickens and improved feed conversion ratio (Rezaeipour and Irani, 2011). Feed conversion ratio improved linearly with increase of soybean oil in the broiler diets (Rezaeipour and Irani, 2011). The FCR was further decreased to 1.87 in Group C. Minimum FCR of 1.94 was recorded in Group $\mathrm{D}$ (Figure 3). Therefore, decreasing the dietary M.E level by 100k.cal $/ \mathrm{kg}$ did not negatively affect the FCR of the birds when their diets were supplemented with the functional oils mixture. These results agree with the findings of (Bess et al., 2012) that the M.E level of feed could be decreased without negatively affecting the FCR of broilers by using functional oils in diet. The improvement in FCR might be due to the anti-microbial activity of castor oil and high digestibility and palatability of soybean oil which resulted in improved digestion, absorption and better utilization of nutrients. Current study is supported by the observations of (Bess et al., 2012) where the M.E level of feed was reduced to $100 \mathrm{k}$.cal and 200k.cal with the addition of functional oils without adversely affecting the FCR of broilers. Comparatively better feed conversion ratio was found in birds fed diet containing refined soybean oil (Hossain and Das, 2014). Supplementing soybean oil and canola oil mixture in broiler feed improved FCR of birds (Nobakht et al., 2011). The resulted better performance of birds could also be attributed to the anti-inflammatory properties of castor oil as cited by (Vieira et al., 2003).

Statistical analysis indicated non-significant difference in relative weight of liver, heart, gizzard, spleen and proventriculus in broilers within the control and treatment group. 
There was significant variation in fat pad weight between the control and treatment group. These results are in agreement with the finding of (Anjum et al., 2004) who reported that vegetable oils showed non-significant differences among relative weight of internal organs (heart, bursa and gizzard).

The data indicates that maximum intestinal length was noted in control Group without functional oils (Figure 4). Decrease in intestinal length in this study agree with the observations of (Ahmad et al., 2006) who reported that the length of intestinal tract was decreased in birds fed fat supplemented ration. They also stated that this result may be an adjustment of body as a result of the addition of fat in ration, which may have decreased the rate of food passage. Digestible part of foods or nutrients is the proportion which is absorbed by the animal, which is not excreted in the feces. It determines the proportion of nutrients in the food that is available for the absorption into the body. $\mathrm{Di}$ gestibility of nutrient is important as it gives the information about the amount of nutrient in the diet and digested by the animals (Case et al., 2010). Soyabean contains maximum level of linolenic acid which displays antibacterial properties, prevents gut misbalances, stabilizes the gut microflora and increases nutrient digestibility (Untea et al., 2011). In addition, dietary fat reduced passage rate of the digesta through the gastrointestinal tract, allowing for better nutrient absorption and utilization (Baião and Lara, 2005; Peebles et al., 2000). Moreover addition of castor oil in feed at low dose increases the digestibility of nutrients (Bess et al., 2012). The increase in ether extract of experimental diets may be attributed to high lipid content of castor oil (Agbabiaka et al., 2011). The crude protein concentration on the diets is inversely proportional to the dietary levels of castor oil. In the present study digestibility was improved by addition of functional oils in the broiler diet as compared to control group (Table 2). Ultimately the addition of Functional oils (Soybean oil and Castor oil) in the broiler diet significantly improves the digestibility of broiler ration.

On the basis of calculations, it was observed that group $\mathrm{B}, \mathrm{C}$ and $\mathrm{D}$ produced maximum net profit as compared to control group $\mathrm{A}$. The feed cost was marginally lower in group $\mathrm{C}$ and $\mathrm{D}$ as compared to group $\mathrm{A}$ and $\mathrm{B}$. This indicates that group $\mathrm{C}$ and $\mathrm{D}$ were economical as compared to group A and B. Due to the high cost of feed ingredient for poultry especially dietary energy, it is important to evaluate the cheap and nutritive natural sources in poultry diets (Pesti et al., 2002). Hence it was concluded that the addition of functional oils $5 \mathrm{ml} / \mathrm{kg}$ in feed with $2900 \mathrm{k}$.cal increased live body weight dressing percentage, enhanced feed digestibility, improved FCR and produced highest net profit.

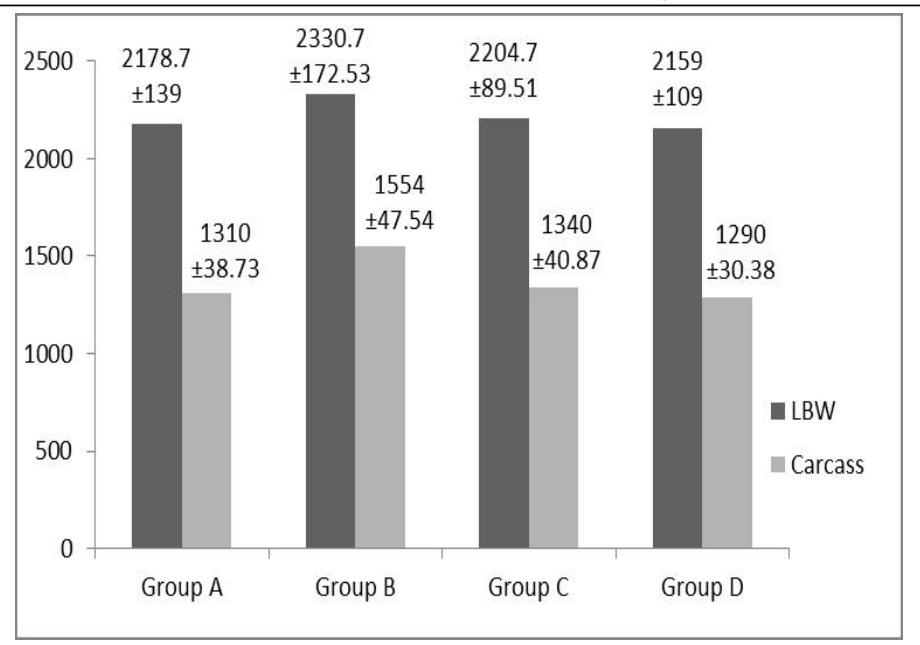

Figure 2: Effect of functional oils on live body and carcass weight of broiler fed different energy level diets

The effect of functional oils on live body weight and carcass weight of broilers fed different energy levels diet. Both were significantly increased $(p<0.05)$ among the groups by using functional oils (Figure 2).

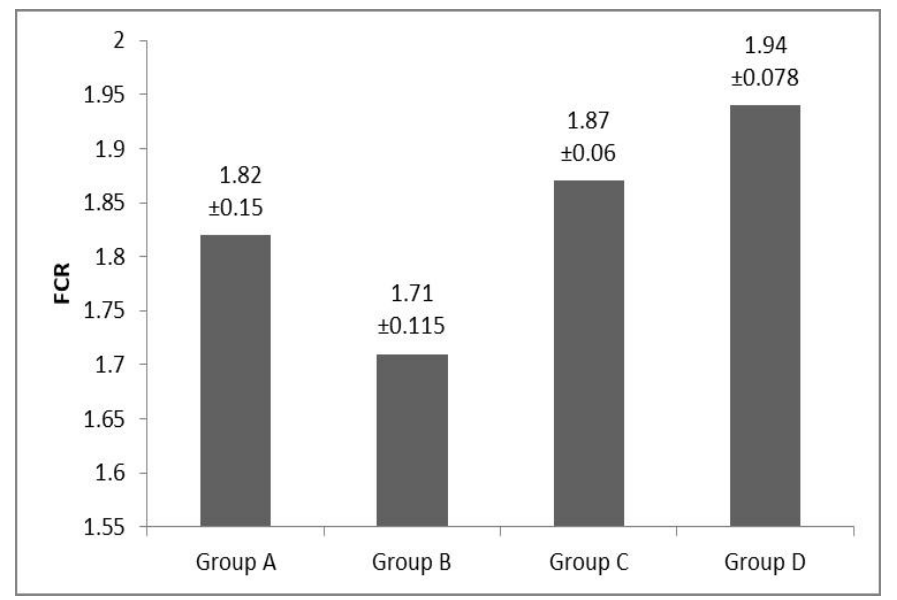

Figure 3: Effect of functional oils on the FCR of broilers fed different energy level diets

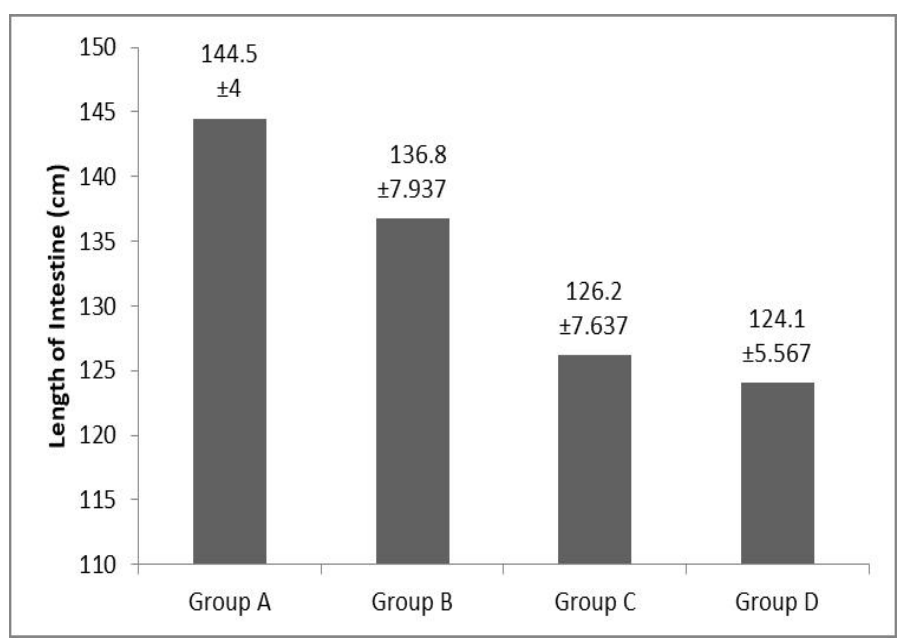

Figure 4: Effect of functional oils on the length of intestine of broilers fed different energy level diets 
Table 1: Contains chemical composition of different energy level diets

\begin{tabular}{llllll} 
S \# & Material & Group A & Group B & Group C & Group D \\
\hline 1 & Rice & 25 & 24.45 & 32.04 & 27.55 \\
\hline 2 & Maize (corn) & 25 & 25 & 15 & 15 \\
3 & Rice polish & 3.5 & 3.5 & 3 & 3 \\
\hline 4 & Fish meal & 8 & 8 & 6.5 & 6.5 \\
\hline 5 & Soyabean meal & 9.56 & 9.56 & 8 & 7 \\
\hline 6 & Guar meal & 3 & 3 & 2.5 & 2.5 \\
\hline 7 & Canola meal & 15 & 15 & 15 & 14 \\
\hline 8 & Sunflower meal & 4 & 4 & 4 & 5 \\
\hline 9 & Wheat bran & 0 & 0 & 8 & 12.49 \\
\hline 10 & C.G 30 & 3 & 3 & 2 & 3 \\
\hline 11 & C.G 60 & 2 & 2 & 1 & 1 \\
\hline 12 & L-lysine & 0.25 & 0.25 & 0.33 & 0.33 \\
\hline 13 & DLM & 0.14 & 0.14 & 0.2 & 0.2 \\
14 & Lime stone & 1 & 1 & 1 & 1 \\
\hline 15 & DCP & 0.2 & 0.2 & 0.5 & 0.5 \\
\hline 16 & Premix & 0.35 & 0.4 & 0.43 & 0.43 \\
\hline 17 & Oil(s) & 0 & 0.5 & 0.5 & 0.5 \\
\hline & Total & 100 & 100 & 100 & 100 \\
\hline & Crude Protein & 21.80 & 21.81 & 20.01 & 20.02 \\
\hline & Metabolizable energy & 2850 & 2900 & 2750 & 2650 \\
\hline
\end{tabular}

Table 2: Digestibility of broilers

\begin{tabular}{lllll} 
Parameter & Groups & & & \\
& A & B & C & D \\
Crude Protein & $74.1^{\mathrm{ab}^{\mathrm{b}}} \pm 2.213$ & $79.35^{\mathrm{a}} \pm 2.654$ & $70.25^{\mathrm{b}} \pm 2.28$ & $68.94^{\mathrm{b}} \pm 2.12$ \\
\hline Ether Extracts & $77.2^{\mathrm{a}} \pm 2.41$ & $80.2^{\mathrm{b}} \pm 2.58$ & $86.3^{\mathrm{ab}} \pm 2.85$ & $81.22^{\mathrm{b}} \pm 2.61$ \\
Metabolizable Energy & $85.1^{\mathrm{a}} \pm 2.82$ & $83.1^{\mathrm{ab}} \pm 2.65$ & $77.3^{\mathrm{b}} \pm 2.21$ & $73.1^{\mathrm{a}} \pm 2.13$
\end{tabular}

Table 3: Relative weight of internal organs

$\begin{array}{lllllllll}\text { Parameter } & \text { Groups } & & & & \mathrm{SE} \pm & \text { LSD } & \text { P-value } \\ & \mathrm{A} & \mathrm{B} & \mathrm{C} & \mathrm{D} & & 0.05 & \\ \text { Liver } & 2.23 \pm 0.017 & 2.25 \pm 0.019 & 2.21 \pm 0.016 & 2.21 \pm 0.016 & 0.0378 & 0.0925 & 0.6507 \\ \text { Heart } & 0.58 \pm 0.21 & 0.59 \pm 0.23 & 0.56 \pm 0.19 & 0.58 \pm 0.21 & 0.0101 & 0.0246 & 0.2134 \\ \text { Gizzard } & 1.07 \pm 0.011 & 1.09 \pm 0.013 & 1.07 \pm 0.011 & 1.08 \pm 0.012 & 0.0136 & 0.0334 & 0.2871 \\ \text { Proventriculus } & 0.59 \pm 0.027 & 0.59 \pm 0.023 & 0.59 \pm 0.024 & 0.60 \pm 0.029 & 0.0170 & 0.0415 & 0.8056 \\ \text { Spleen } & 1.57 \pm 0.015 & 1.59 \pm 0.018 & 1.57 \pm 0.014 & 1.55 \pm 0.012 & 1.0270 & 2.5140 & 0.1139 \\ \text { Fat pad } & 2.0 \pm 0.072 & 2.80 \pm 0.094 & 1.90 \pm 0.65 & 1.70 \pm 0.63 & 1.0658 & 2.8910 & 0.0397\end{array}$

Table 4: Economics of broilers

\begin{tabular}{|lllll|}
\hline Particulars & Group A & Group B & Group C & Group D \\
\hline Day-old chicks (Rs/chick) & 26.50 & 26.50 & 26.50 & 26.50 \\
\hline Feed consumed (kg/chick) & 3.97 & 4.0 & 4.13 & 4.11 \\
\hline Rate of feed(Rs/kg) & 43.00 & 43.00 & 39.00 & 38.00 \\
\hline Feed cost (Rs/bird) & 170.71 & 172 & 161.07 & 156.18 \\
\hline Treatment cost (Rs/bird) & 0 & 7.22 & 7.22 & 7.22 \\
\hline
\end{tabular}

December 2018 | Volume 6 | Issue 4 | Page 32 


\begin{tabular}{|llllll}
\hline Medication(Rs/bird) & 5 & 5 & 5 & 5 \\
\hline Brooding cost (Rs/bird) & 15 & 15 & 15 & 15 \\
\hline Miscellaneous (Rs/bird) & 5 & 5 & 5 & 5 \\
\hline Total cost(Rs/bird) & 222.21 & 226.42 & 219.79 & 218.32 \\
\hline Marketing price (Rs/kg live weight) & 105 & 105 & 105 & 105 \\
\hline Live body weight & 2.17 & 2.33 & 2.20 & 2.15 \\
\hline Total Income (Rs/bird) & 227.85 & 244.65 & 231 & 225.75 \\
\hline Net profit (Rs/bird) & 5.64 & 18.23 & 11.21 & 7.43 \\
\hline
\end{tabular}

Results of relative weight of edible and non-edible organs are shown in Table 3.

Statistical analysis showed non-significant difference ( $\mathrm{p}>$ 0.05 ) except for the relative weight of fat pad where significant difference $(\mathrm{p}<0.05)$ was observed among the groups.

Table 4 shows the effects of functional oils on the economics of broilers. This reveals that functional oils are more economical when used in weak and cheap diets.

\section{ACKNOWLEDGEMENTS}

We are thankful to the lab techniciansfor their excellent lab assistance at the poultry facility in the department of Poultry Husbandry, Sindh Agriculture University,Tandojam, Pakistan.

\section{CONFLICT OF INTEREST}

There is no conflict of interest.

\section{AUTHORS CONTRIBUTION}

Irfan Jan and Laiba Uroog has carried out the research work and written the manuscript. Abdul Kabir carried out the statistical data analysis. Shumaila Manzoor has co-supervised the research work. Muhammad Said has supervised and provided the funding for this research work.

\section{REFERENCES}

- Agbabiaka L, Amadi S, Oyinloye G, Adedokun I, Ekeocha C (2011). Growth response of African catfish (Clarias gariepinus, Burchell 1822) to dried rumen digesta as a dietary supplement. Pakistan J. Nutr. https://doi.org/10.3923/ pjn.2011.564.567

- Ahmad F, Mahmood S, Zia-Ur-Rehman AM, Alam M, Muzaffar A (2006). Effect of feeding management on energy, protein intake and carcass characteristics of broilers during summer. Int. J. Agric. Biol. 8: 546-549.

- Ajuyah A, Ahn D, Hardin R, Sim J (1993). Dietary antioxidants and storage affect chemical characteristics of $\omega-3$ fatty acid enriched broiler chicken meats. J. Food Sci. 58: 43-46. https://doi.org/10.1111/j.1365-2621.1993.tb03206.x

- Aliyu R, Egwu E, Abubakar M, Adamu A, Salihu M, Dabai A, Tambuwal F (2012). Bacteriological quality of commercially prepared and self compounded poultry feeds in Sokoto metropolis, Sokoto, Nigeria. Int. J. Appl. Biol. Pharm. Technol 3: 345-350.

- Anjum M, Mirza I, Khan A, Azim A (2004). Effect of fresh versus oxidized soybean oil on growth performance, organs weights and meat quality of broiler chicks. Pakistan Vet. J. 24: $173-178$.

- Babatunde B (2005). Effects of feeding graded levels of kolanut husk meal on the performance of cockerels. Nigerian J. Anim. Prod. 32: 61-66.

- Baião NC, Lara L (2005). Oil and fat in broiler nutrition. Brazilian J. Poult. Sci. 7: 129-141. https://doi.org/10.1590/ S1516-635X2005000300001

- Bess F, Favero A, Vieira S, Torrent J (2012). The effects of functional oils on broiler diets of varying energy levels. J. Appl. Poult. Res. 21: 567-578. https://doi.org/10.3382/ japr.2011-00481

- Case L, Daristotle L, Hayek M, Raasch M (2010). Canine and feline nutrition: a resource for companion animal professionals 3rd edn. In. Elsevier Health Sciences, Maryland Height, Missouri, City.

- Firman JD, Kamyab A, Leigh H (2008). Comparison of fat sources in rations of broilers from hatch to market. Int. J. Poult. Sci. 7: 1152-1155. https://doi.org/10.3923/ ijps.2008.1152.1155

- Firman JD, Leigh H, Kamyab A (2010). Comparison of soybean oil with an animal/vegetable blend at four energy levels in broiler rations from hatch to market. Int. J. Poult. Sci. 9: 1027-1030. https://doi.org/10.3923/ijps.2010.1027.1030

- Hossain M, Das G (2014). Effect of Crude Soybean Oil Sediment as a Substitute for Refined Soybean Oil in Broiler Diet. Iranian J. Appl. Anim. Sci. 4.

- Huang K, Kemp C, Fisher C (2011). Effects of nutrition on water intake and litter moisture in broiler chickens. In: 22 nd Annual Australian Poult. Sci. Sympos. p. 26.

- Navidshad B (2009). Effects of fish oil on growth performance and carcass characteristics of broiler chicks fed a low-protein diet. Int. J. Agr. Biol. 11: 635-638.

- Nobakht A, Tabatbaei S, Khodaei S (2011). Effects of different sources and levels of vegetable oils on performance, carcass traits and accumulation of vitamin $\mathrm{E}$ in breast meat of broilers. Curr. Res. J. Biol. Sci. 3: 601-605.

- Peebles ED, Zumwalt C, Doyle S, Gerard P, Latour M, Boyle C, Smith T (2000). Effects of dietary fat type and level on broiler breeder performance. Poult. Sci. 79: 629-639. https:// doi.org/10.1093/ps/79.5.629

- Pesti G, Bakalli R, Qiao M, Sterling K (2002). A comparison 
of eight grades of fat as broiler feed ingredients. Poult. Sci. 81: 382-390. https://doi.org/10.1093/ps/81.3.382

- Rajput N, Muhammah N, Yan R, Zhong X, Wang T (2012). Effect of dietary supplementation of curcumin on growth performance, intestinal morphology and nutrients utilization of broiler chicks. J. Poult. Sci. 0120065.

- Rezaeipour V, Irani M (2011). Effects of dietary alpha tocopherol acetate and soybean oil on growth performance and meat oxidative stability of broiler chicks. J. Cell Anim. Biol. 5: 271-274.

- Salma U, Miah A, Maki T, Nishimura M, Tsujii H (2007). Effect of dietary Rhodobacter capsulatus on cholesterol concentration and fatty acid composition in broiler meat. Poult. Sci. 86: 1920-1926. https://doi.org/10.1093/ ps/86.9.1920

- Scaife J, Moyo J, Galbraith H, Michie W, Campbell V (1994). Effect of different dietary supplemental fats and oils on the tissue fatty acid composition and growth of female broilers. Brit. Poult. Sci. 35: 107-118. https://doi. org/10.1080/00071669408417675

- Serrano M, Frikha M, Corchero J, Mateos G (2013). Influence of feed form and source of soybean meal on growth performance, nutrient retention, and digestive organ size of broilers. 2. Battery study. Poult. Sci. 92: 693-708. https://doi. org/10.3382/ps.2012-02372

- Untea A, Criste R, Panaite T, Costache I (2011). Effect of the dietary oregano (Origanum vulgare) on $\mathrm{Cu}$ and $\mathrm{Zn}$ balance in weaned piglets. J. Trace Elemen. Med. Biol. 25: S35-S40 https://doi.org/10.1016/j.jtemb.2010.10.011.

- Vieira S, Lima I, Borges C, Fernandes L, Quadros V (2003). Broiler utilization of vegetarian diets. Poult. Sci. 82: 38.

- Zollitsch W, Knaus W, Aichinger F, Lettner F (1997). Effects of different dietary fat sources on performance and carcass characteristics of broilers. Anim. Feed Sci. Technol. 66: 6373. https://doi.org/10.1016/S0377-8401(96)01126-1 